\title{
DETERMINANTS OF HOUSING TENURE CHOICE IN NEW
} ZEALAND

\author{
BOB HARGREAVES \\ Massey University
}

\begin{abstract}
Over the last 15 years, the rate of home ownership in New Zealand has declined from $73 \%$ to $67 \%$. The reasons for this decline are not clear, because there has been a lack of up-to-date research focusing on the determinants of housing tenure choice. This paper reports on a survey of private sector renters carried out in 2002. Respondents were asked to identify perceived impediments to ownership, and financial considerations were the main reason for renters not switching to home ownership. Difficulties in saving for a deposit on a house and the need to pay off existing debt were the main financial reasons cited. Lack of job security and the conflict between work and raising a family were also reported as being important.
\end{abstract}

Hedonic models confirm the importance of household income as one of the key variables determining household tenure, particularly in the lower rent suburbs. The percentage of the population that are married was the dominant variable influencing the percentage of houses rented.

Keywords: Home ownership, tenure choice, housing affordability, New Zealand.

\section{INTRODUCTION}

When faced with the decision of whether to rent or buy housing, most New Zealanders select the ownership option. According to Christiansen (1991), in 1986, New Zealand had possibly the highest rate of ownership in the world (73.7\%). Statistics New Zealand (1998) figures from the 1996 census showed home ownership at $70.5 \%$. Final results from the 2001 census show the ownership rate at $67 \%$, a level last seen in 1956 . Clearly renting has become the preferred option for an increasing percentage of households.

A search of various government websites and the release of EU ownership statistics by Haffner \& Dol (2000) shows New Zealand has slipped down the international rankings and is now only just in the top ten. Singapore (90\%) is the leader in owner occupied housing, followed by Taiwan $(85 \%)$, Spain $(80 \%)$ and Ireland (79\%). While New Zealand has been slowly going backwards in the home 
ownership stakes, a number of other countries have been making rapid progress in increasing the percentage of homeowners.

A variety of reasons have been suggested for the decline in home ownership in New Zealand. Some of these reasons are unique to New Zealand, while others are common across most western countries. They include labour market and societal changes as well as financial considerations. For example, the corporate downsizing and global competition, identified by Knight \& Eakin (1997) has resulted in shorter employment contracts and reduced job security. Research by Green and Hendershott (1999) showed renters are more flexible than owners in being able to move quickly to take advantage of new job opportunities, although according to Fisher (2002), there is some debate about generalising this finding. Societal changes favouring renting relate to the tendency of families to form later and delay marriage and having children.

Researchers such as Goodman (1988, 2002), Bourassa (1995, 2000) and Kan (2000) have developed theoretical tenure choice models using a variety of variables and modelling techniques. Income variability is normally one of the key drivers in these models. According to Hargreaves (2002), the most important financial variables influencing the rent versus buy decision are thought to be duration of ownership, house price appreciation and affordability. In New Zealand, student debt repayment is also likely to be a consideration for first homeowners when both saving for a deposit and servicing a mortgage.

\section{RESEARCH OBJECTIVES}

While many reasons have been put forward for the decline in home ownership rates, there is a lack of up-to-date research focusing on the determinants of housing tenure choice in New Zealand.

The first objective of this project was to investigate renter household attitudes and preferences regarding tenure choice. Respondents were asked to identify perceived impediments to ownership (if any) and rank these in order of importance. The mail questionnaire was followed up by 45 telephone interviews with a random sample of Auckland renters, so that some of the key issues could be explored in greater depth.

The second objective of the research was to investigate the relationship between renter's attitudes and demographic data from Census 2001, which shows demographic, household tenure and household income data down to a suburb level. 


\section{METHODOLOGY}

Renter household attitudes were assessed by mail questionnaire. The random sample of 2,000 renter households was drawn from the Ministry of Housing Tenancy Bond Centre (2002) database of private sector renters. There are approximately 250,000 private sector rental households in New Zealand. If a landlord takes a bond from a tenant, there is a legal requirement under the Residential Tenancies Act for the bond money to be lodged with the Ministry of Housing. Since it makes good business sense to take a bond, the Tenancy Bond Centre database is very comprehensive and records over 100,000 new tenancies per year. The random sample provided coverage of the main cities as shown in Table 1.

Table 1: NZ renter household survey: 2002

\begin{tabular}{|l|c|c|c|}
\hline Area & Population of city & Percent of sample & Sample size \\
\hline North Shore & 184,821 & 11.6 & 231 \\
Waitakere & 168,750 & 10.6 & 211 \\
Auckland & 367,734 & 23.0 & 460 \\
Manukau & 283,200 & 17.7 & 354 \\
Wellington & 163,824 & 10.2 & 205 \\
Christchurch & 316,227 & 19.8 & 396 \\
Dunedin & 114,342 & 7.2 & 143 \\
\hline Total & $1,598,898$ & 100 & 2000 \\
\hline
\end{tabular}

The questionnaire and covering letter were agreed to by the Ministry of Housing who also arranged for the mail out. To protect the privacy of the individuals being surveyed, the mail out was done through a third party specialising in this type of work. This meant the researcher had no idea who received the questionnaires unless respondents choose to identify themselves.

The questionnaire was in a semi-structured format, listing the most obvious variables under the main categories; lifestyle, career and financial. Respondents were given room to add variables. They were then asked to rank the variables within each main category and also rank the main categories. Since tenure choice was thought to be a function of age, income, family size, location and stage in the family cycle, respondents were asked to supply these demographic details. Questionnaires were mailed to the head of the household. For analysis of the questionnaires, the author utilised SPSS (Norusis, 1996).

\section{Response rate}

Of the 2000 questionnaires that were mailed, a total of 360 usable responses had been received by June 2002, representing an $18 \%$ response rate. Approximately 20 
questionnaires $(1 \%)$ were returned, either due to a wrong address or because the tenant had moved without providing a forwarding address. The response rate was considered adequate to validate the results. ${ }^{1}$

\section{Questionnaire results}

The first section investigated attitudes of renter households to housing tenure choice. A Likert scale was used and respondents were asked to agree or disagree with a statement on a 1-5 scale, where 1 represented strong agreement, 5 represented strong disagreement and 3 represented a neutral position of neither agreeing or disagreeing.

\section{SECTION 1}

Q1. Buying a house is a priority for me/us.

There was strong agreement with this statement. Buying a house was a priority for $45 \%$ of respondents, $25 \%$ were neutral and the rest disagreed to some extent. The timing of when the respondents might be able to buy was covered later in the survey at question 21 .

Q2. Paying rent is money down the drain when I/we could be paying off a mortgage.

The majority of respondents $(60 \%)$ agreed with this statement. Clearly, renting was not the preferred option for most respondents.

Q3. I/we don't want to be tied down by owning a house.

Only $21 \%$ of respondents agreed with this statement, $18 \%$ were neutral and $61 \%$ disagreed.

Q4. I/we would rather spend time on recreational activities than maintaining a house.

There was little support for this statement. Only $23 \%$ of respondents agreed, $24 \%$ were neutral and 53\% disagreed.

Q5. Renting provides me/us with more money to spend on myself/ourselves. There was general disagreement here, as $57 \%$ disagreed, $21 \%$ were neutral and the balance $(22 \%)$ agreed.

Q6. I/we do not have sufficient job security to commit to buying a house.

Lack of job security is clearly an important issue, with $51 \%$ of respondents agreeing with the statement, $14 \%$ being neutral and 35\% disagreeing.

\footnotetext{
${ }^{1}$ The response rate would have been improved if a reminder letter had been sent out. However, there were some logistical problems with the timing of a reminder letter, due to the complex way the mailings had to be done, and in the end, a reminder was not sent out.
} 
Q7. It is not worth buying a house because I/we change addresses so often. In this case, $83 \%$ of respondents disagreed with the statement, $8 \%$ were neutral and only $9 \%$ agreed.

Q8. I/we have accommodation provided as part of our employment package. Only $2 \%$ of respondents had accommodation provided as part of their employment package.

Q9. I/we now have sufficient income and other assets to save the necessary money for a deposit to purchase a house.

The deposit barrier is clearly an issue, with $59 \%$ of respondents disagreeing, $9 \%$ neutral and $32 \%$ agreeing.

Q10. I/we now have sufficient income to be confident of securing a mortgage to assist with the purchase of a house.

The responses to question 10 were similar to question 9 since servicing a mortgage is a barrier to ownership. Only $26 \%$ of respondents thought they could manage mortgage payments, $11 \%$ were neutral and $63 \%$ had insufficient debt servicing capacity.

Q11. If I/we bought a house now, I/we would be a cash buyer and not require a mortgage.

As might be expected from the answers to questions 9 and 10 , very few respondents were likely to be cash buyers. Overall, $86 \%$ of respondents disagreed with the statement and only $10 \%$ agreed.

Q12. I/we are unlikely to buy a house until existing debts are repaid.

Existing debt is clearly an impediment to ownership, since it is hard to save for a house whilst repaying car loans etc. $52 \%$ of respondents agreed that existing debt was an issue, $16 \%$ were neutral and $32 \%$ disagreed.

Q13. Student debt is the largest component of my/our existing debt.

Although there has been a lot of media attention devoted to the growing problem of student debt, it turns out that people with student debt are only a small proportion of the total number of private sector renters. Only $20 \%$ agreed with the statement, $5 \%$ were neutral and $75 \%$ disagreed.

Q14. I/we can afford to buy a house now but choose not to because there are better returns to be made elsewhere.

There was strong disagreement with this statement (74\%), 11\% were neutral and $14 \%$ agreed. This response was not surprising, given most people had difficulty saving for a deposit and were unlikely to be investing in the financial markets. 
Q15. My/our income level and ability to service a mortgage is likely to increase substantially within the next 3 years.

There was significant agreement with this statement, with $37 \%$ agreeing, $21 \%$ neutral and $42 \%$ disagreeing.

Q16. To make it worthwhile buying, the annual average rate of increase for the value of houses in my area would need to be in the following range.

Respondents were given four options, $<1 \%$ pa, 1 to $2.5 \%$ pa, 2.5 to $5 \%$ pa and $>5 \%$ pa. This was seen as a difficult question to answer and not too much can be read into the responses, as most people tend not to think much about this issue. The spread of responses was fairly even at $26 \%, 23 \%, 30 \%$ and $21 \%$ respectively.

\section{SECTION 2}

This section of the questionnaire asked the respondents to rank the sub-factors causing them to rent rather than own a house under the headings of financial constraints, job constraints and lifestyle constraints.

Figure 1: (Q17) Financial constraints ranking (1-5)

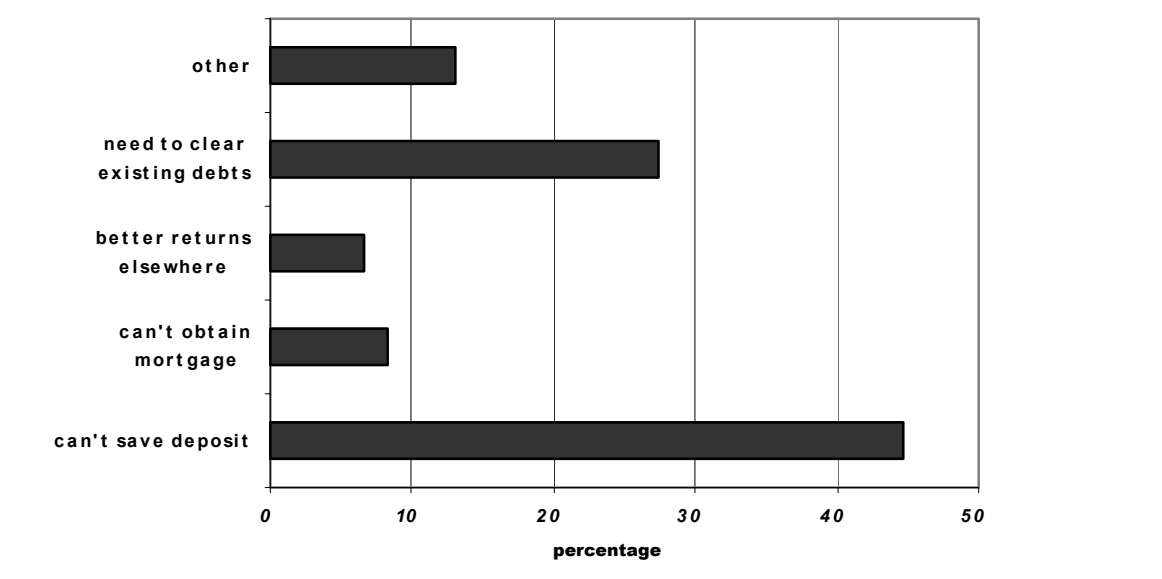

The data in Figure 1 represents the percentage of respondents ranking each item as the first constraint. Thus the responses sum to $100 \%$. The responses are clearly linked in some cases. For example, the deposit barrier is the number one financial constraint and is linked to the second ranked constraint, the need to clear existing 
debts. Clearly most renters will find it hard to accumulate a deposit before repaying existing debt. ${ }^{2}$

Figure 2: (Q18) Job constraints ranking (1-4)

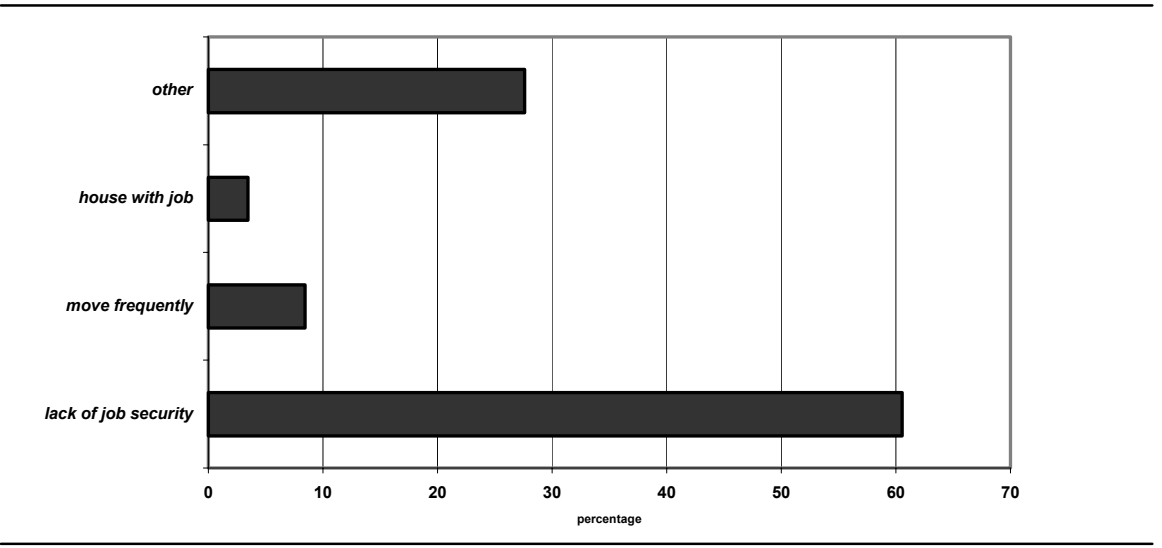

Lack of job security dominated the responses to this question, with $61 \%$ of respondents ranking this as the number one job constraint. ${ }^{3}$

Figure 3: (Q19) Lifestyle constraints ranking (1-4)

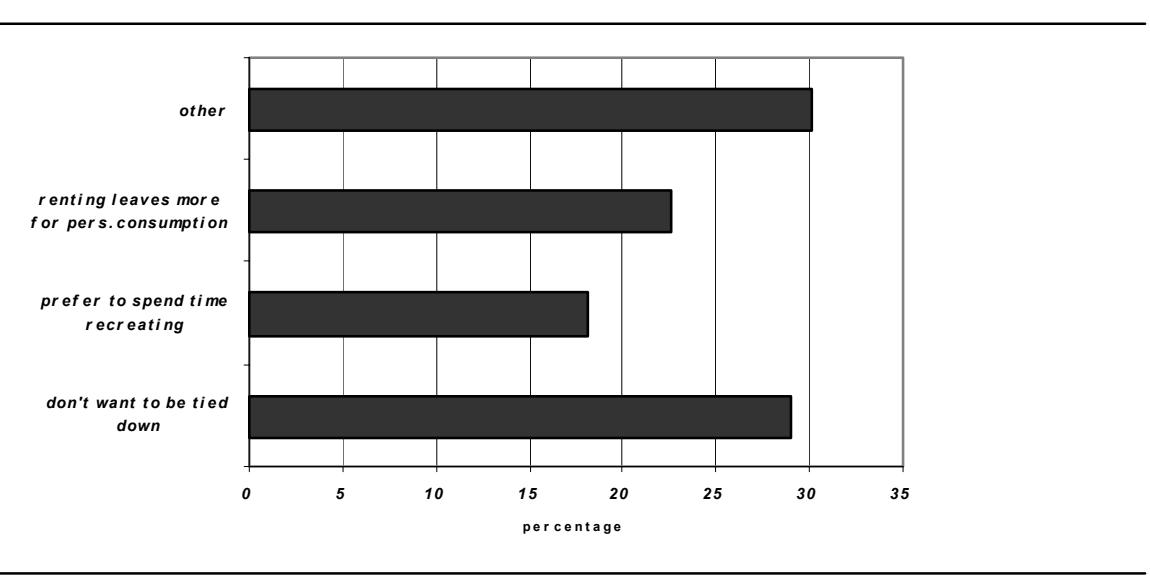

\footnotetext{
${ }^{2}$ Reasons that respondents placed under "other" included people being currently in training or transition, presently buying or selling a house, owning a house at another location, aversion to mortgage debt, renting as a better deal and placing a higher priority on spending on other items.

${ }^{3}$ Reasons recorded under "other" were age related issues such as being near retirement, those on various welfare or unemployment benefits or undecided where to put their roots down.
} 
This response was dominated by "other". 4

Figure 4: (Q20) Overall ranking of constraints (1-4)

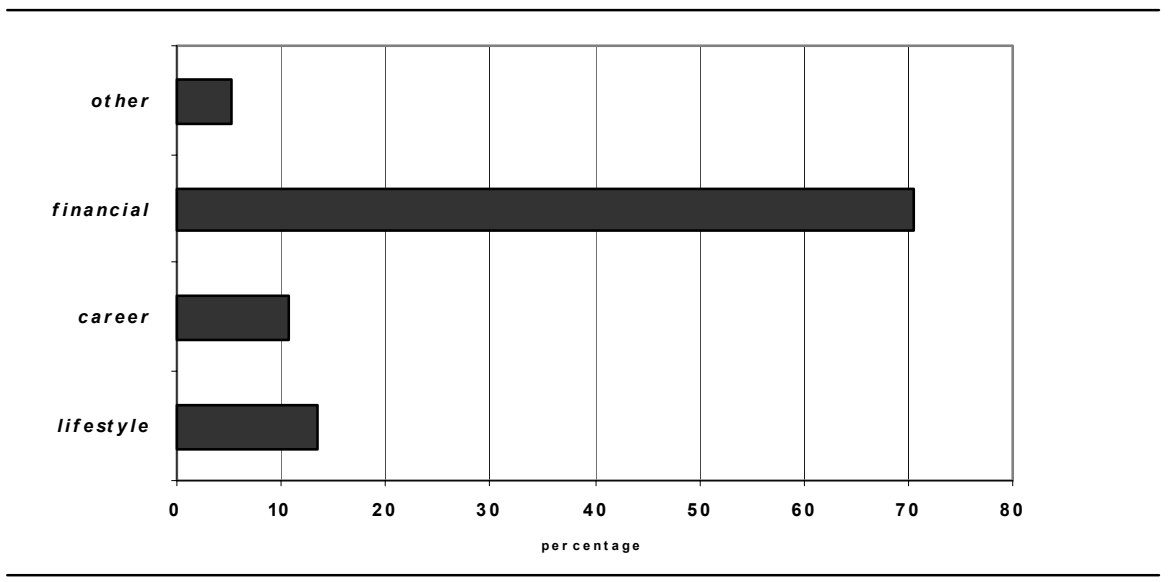

When the respondents were asked to give an overall ranking of the constraints to buying, financial constraints were ranked the most important $(70 \%)$. Next came lifestyle at $14 \%$, followed by career at $11 \%$ and other at $5 \%$. These results are quite stark. The affordability barrier to home ownership is clearly the most important constraint on the population of private sector renters.

Although $40 \%$ of respondents had no plans to buy, the remaining $60 \%$ did plan to buy within the next 10 years and of these, half planned to buy in 3 years or less. These responses give some credence to the premise that home ownership is still a very important part of the "Kiwi dream", at least for most renters.

This question was cross-tabulated against the age of the respondents. Peak time to buy appears to be in the 25-39 age bracket. As might be expected, there was a strong correlation between the respondent's income level and the time to buy. Clearly an affordability gap exists in the lower income brackets and purchase decisions normally require more than one earner in the household.

\footnotetext{
${ }^{4}$ The main issue under "other" was the perceived conflict between family time and home ownership. A number of respondents said that in order to maximise their time with the children only one partner could work, usually the male. This meant that ownership was out of reach for single income families, except those on high incomes. Other reasons were people not ready to settle down with a partner and those who did not want to take in flat mates in order to pay the mortgage.
} 
Figure 5: (Q21) Please indicate the most likely time when you will switch from renting to owning your own home

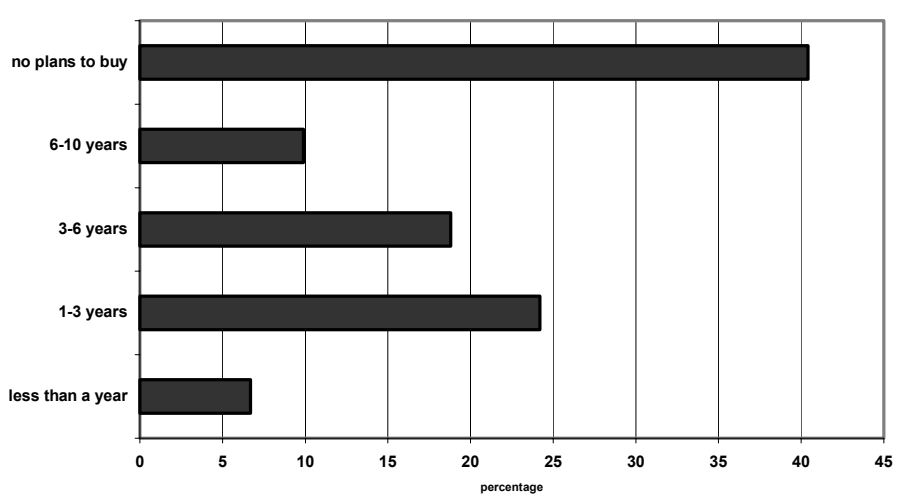

\section{SECTION 3}

This section asked questions about the personal circumstances of the respondents, following a similar format to that used in the 5 yearly census.

Q22. What is your gender?

Female responses dominated the replies at $62 \%$.

Q23. Please select your age range.

Respondents were fairly evenly spread across the 25-49 age groups, with $26 \%$ being aged 50 and over.

Q24. Please indicate the suburb and city where you usually live.

Responses were Auckland 52\%, Christchurch 25\%, Wellington 15\% and Dunedin $8 \%$.

Q25. How long have you lived at your present address?

Approximately $60 \%$ of respondents had been at their present address for 3 years or less. This confirms the mobility of the population of renters.

Q26. Where did you live 5 years ago?

Most respondents had lived elsewhere in New Zealand 5 years ago (56\%), 13\% were overseas and the $31 \%$ at their present address.

Q27. Have you previously owned a house?

Surprisingly, $36 \%$ of respondents had previously owned a house. When this data was analysed in more depth, it was found that a significant number of these respondents had either been overseas or moved into a more expensive housing 
market. The other main group was people who had had a marital problem and had lost the family home.

Q28. Please indicate the ethnic group(s) you belong to.

New Zealand Europeans dominated at $67 \%$, followed by Maori $14 \%$ and Pacific Islander 9\%.

Q29. Please tick as many spaces as you need to show all the people who live in the same household as you.

As expected, the typical household was one or two adults living with their children.

Q30. Apart from secondary school qualification, do you have another higher qualification?

The majority of respondents (58\%) answered yes to this question.

Figure 6: (Q31) My annual income is:

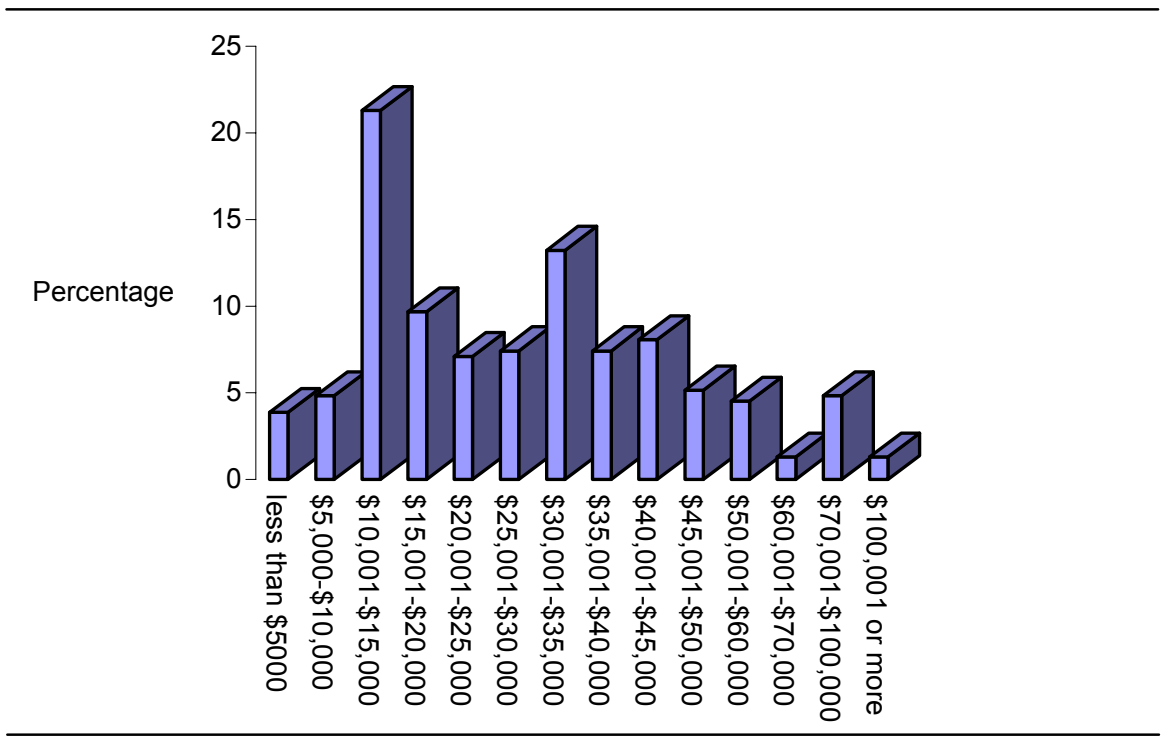

The vertical axis maps the percentage of respondents in each income bracket. The large group in the $\$ 10,000-\$ 15,000$ category is largely a function of the number of recipients of various forms of government assistance, including for solo parents, unemployed, pensioners and sickness beneficiaries. The sample also included people in training and university students. The net result is a lot of people on below average incomes. 
Q32. Number of incomes available to assist with house purchase.

This is an important question as it is very difficult for single income families on average or below average incomes to purchase a house, particularly in the Auckland region. $64 \%$ of respondents only had one income, $31 \%$ had two incomes and $5 \%$ had more than two incomes.

\section{Q33. Number of residents in household.}

There were $22 \%$ one-person households, $29 \%$ two-person households, $18 \%$ threeperson households, $17 \%$ four-person households and the balance were larger than four.

Q34. I am on the waiting list for Housing Corp rental house.

Only $3 \%$ of the respondents were on the Housing Corporation waiting list.

\section{Summary of conclusions from questionnaire}

The clear message that comes out of this survey is that financial considerations dominate the reason why more renters aren't switching to ownership. The main financial problem is the deposit barrier. In particular, single income householders have difficulties saving for a deposit. There is a real conflict between householders spending time away from the work force rearing their children and the need to accumulate savings. The deposit gap is most difficult in Auckland, because wage rates in Auckland do not offset Auckland house prices. It is therefore no surprise that Auckland has the highest percentage of rental houses. Lack of job security also showed up as an important tenure choice issue.

\section{Validation of questionnaire results}

The importance of household income in determining tenure choice decisions confirms the findings of Chapman (1981) who used survey data from Auckland to show that the main barrier to ownership was lack of financial resources. In addition, O'Dea (2000) analysed New Zealand income data over the period 19811996 and found the proportion of middle income earners had fallen, with the proportion of both high income and low income earners increasing. Pahl (1998) says this type of income inequality can lead to social polarisation.

The relatively low response rate from the mail questionnaire raised questions about the non-respondents. In an effort to remedy this problem, follow-up work was done using telephone interviews of private sector renters in Auckland. The results of 45 telephone interviews confirmed the overall findings from the mail questionnaire as reported above.

The Massey University Real Estate Analysis Unit (MUREAU) has developed a long-run Home Mortgage Affordability Series as reported by Crews and Hopkins (1999) and now published under the auspices of AMP Banking (2002). The variables used in this index are median house prices, average wage rates and 
mortgage interest rates. Over the period February 1989 to May 2002, on average, affordability worsened in New Zealand by $32 \%$.

Interest rates in New Zealand have been very volatile over the last 20 years and this can distort short-run affordability considerations. Another way of looking at affordability is to use the Auckland Regional Council's (1999) approach, using the ratio of incomes to house prices. Their study showed the long run ratio of average wages to median house prices in Auckland has continued to decline. This work is extended below to include selected areas outside Auckland. Figure 6 shows regional data from 1992-2002 for Auckland, Wellington and Christchurch. Over this period, the Auckland ratio increased by $46 \%$, followed by Wellington $28 \%$ and Christchurch 7\%. Affordability is most difficult in Auckland which has the highest percentage of rental housing amongst the main cities. The main reason behind the deterioration in the purchase ratio is that house prices have continued to increase faster than wages and salaries. By June 2002, the Quotable Value NZ (2002) house price index for Auckland had increased to 2082, compared with Wellington 1640, Christchurch 1580, Invercargill 1252 and all New Zealand 1701. The index was set at 1000 in December 1989.

Figure 6: Income purchase ratios: 1992-2002

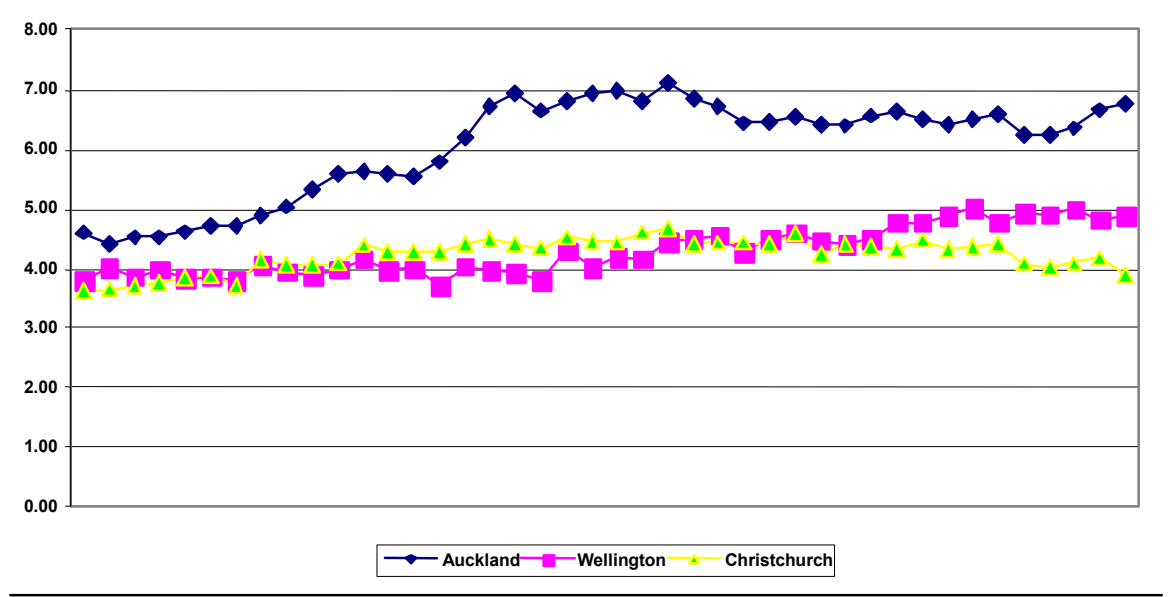

\section{ANALYSIS BY AREA UNITS}

In line with the second objective of the study, an analysis of Statistics New Zealand data $(2001,2002)$ was undertaken to determine the relationship between various demographic and household data and tenure choice. Since the Auckland region has consistently been the least affordable in New Zealand, it was decided to use Auckland data from census 2001 to see if there was a correlation between the 
median household income in a suburb and the percentage of houses rented. Several hedonic models were developed to attempt to quantify this relationship. The variables used in the first model are explained in Table 2 below. There were 296 suburbs included from the four main cities comprising the Auckland region.

The matrix of correlation coefficients is shown in Appendix 1 and a summary of models in Table 3. An examination of Table 3 shows the explanatory power of the model is reasonably good, with an $\mathrm{R}$ squared statistic of .806 and a standard error of estimate of $5.37 \%$. Also the signs on the coefficients were as expected for the independent variables. However, the main driver in the equation is the percentage of people married (-.854) rather than household incomes. Thus, as the percentage of people married increases, the percentage of rental houses in an area unit decreases. Household income is still an important variable (-.460), but as shown in Appendix 1, its influence is diminished by the fact that people adjust their housing consumption according to their incomes and the income variable is strongly correlated (.733) to the median rent variable. As expected, the percentage of people married is negatively correlated, with the percentage in the 20-34 age group, signifying the married population representing people on higher than average incomes and household more likely to have more than one income earner. Also as expected, the percentage Maori was strongly correlated to income (-.498) and rents (-.616). The signs on the dummy variables were as expected and explained by higher levels of rent in Auckland City followed by North Shore City.

Table 2: Model variables

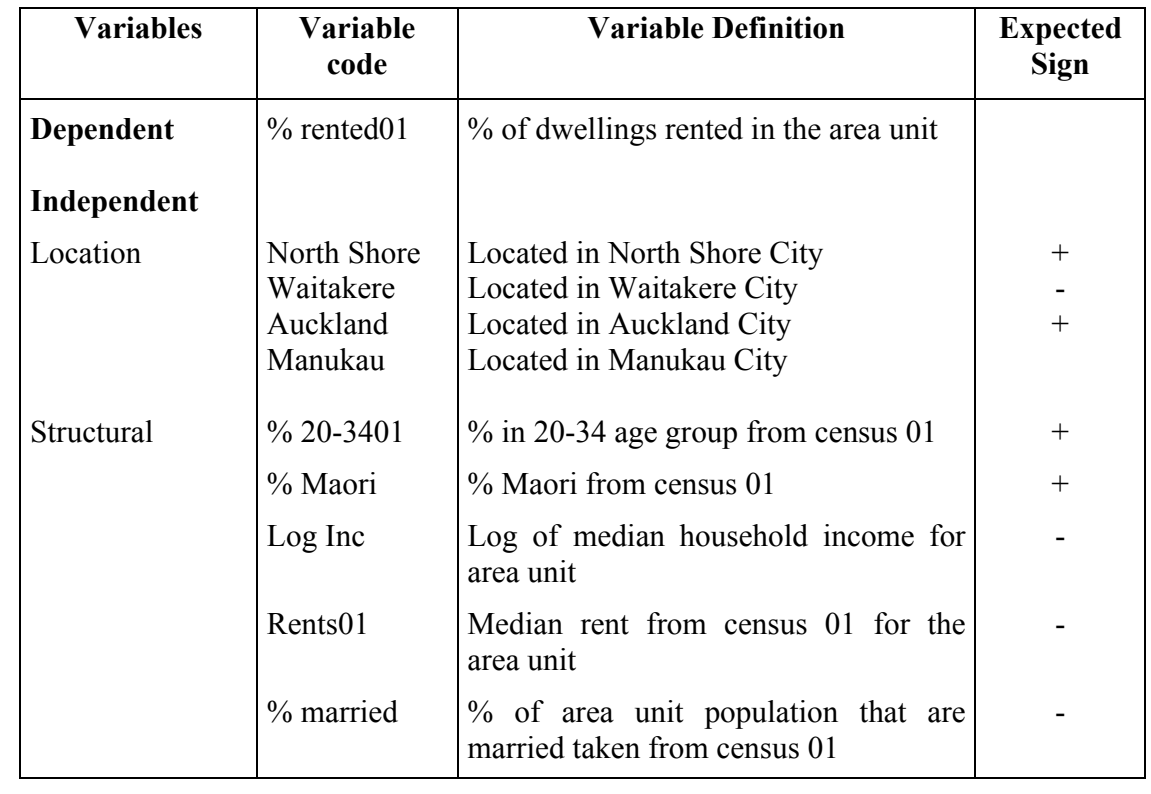


The model was then simplified and two variables were transformed into one in an effort to overcome the autocorrelations shown in Appendix 1. The new model includes a hybrid variable to represent income and the percentage married. The form of the new variable (V37) is log income multiplied by the percentage married. This model is shown in Table 4.

Table 3: Model summaries: Auckland region models

\begin{tabular}{|c|c|c|c|c|c|c|c|c|}
\hline & $\mathrm{R}$ & R Square & $\begin{array}{l}\text { Adjusted } \\
\text { R Square }\end{array}$ & $\begin{array}{l}\text { Std. Error } \\
\text { of the } \\
\text { Estimate }\end{array}$ & $\begin{array}{l}\text { Change } \\
\text { Statistics }\end{array}$ & & & $\begin{array}{l}\text { Durbin- } \\
\text { Watson }\end{array}$ \\
\hline Model & & & & & $\begin{array}{l}\text { R Square } \\
\text { Change }\end{array}$ & F Change & $\begin{array}{c}\text { Sig. F } \\
\text { Change }\end{array}$ & \\
\hline 1 & .854 & .729 & .728 & 6.374 & .729 & 791.868 & .000 & \\
\hline 2 & .873 & .762 & .760 & 5.989 & .033 & 40.780 & .000 & \\
\hline 3 & .890 & .793 & .791 & 5.588 & .031 & 44.072 & .000 & \\
\hline 4 & .895 & .801 & .798 & 5.486 & .008 & 11.998 & .001 & \\
\hline 5 & .898 & .807 & .803 & 5.415 & .006 & 8.683 & .003 & \\
\hline 6 & .900 & .810 & .806 & 5.374 & .004 & 5.505 & .020 & 1.362 \\
\hline \multicolumn{9}{|c|}{$\begin{array}{l}\text { Model 1: Predictors: (Constant), \% married01 } \\
\text { Model 2: Predictors: (Constant), \% married01, Waitakere } \\
\text { Model 3: Predictors: (Constant), \% married01, Waitakere, Log Inc } \\
\text { Model 4: Predictors: (Constant), \% married01, Waitakere, Log Inc, Auckland } \\
\text { Model 5: Predictors: (Constant), \% married01, Waitakere, Log Inc, Auckland, Rents01 } \\
\text { Model 6:Predictors: (Constant), \% married01, Waitakere, Log Inc, Auckland, Rents01, \% } \\
\quad \text { Maori01 }\end{array}$} \\
\hline
\end{tabular}

Table 4: Model summary: Auckland region hybrid model

\begin{tabular}{|c|c|c|c|c|c|c|c|c|}
\hline & R & R Square & $\begin{array}{c}\text { Adjusted } \\
\text { R Square }\end{array}$ & $\begin{array}{c}\text { Std. Error } \\
\text { of the } \\
\text { Estimate }\end{array}$ & $\begin{array}{c}\text { Change } \\
\text { Statistics }\end{array}$ & & & $\begin{array}{c}\text { Durbin- } \\
\text { Watson }\end{array}$ \\
\hline Model & & & & & $\begin{array}{c}\text { R Square } \\
\text { Change }\end{array}$ & F Change & $\begin{array}{c}\text { Sig. F } \\
\text { Change }\end{array}$ & \\
\hline 1 & .860 & .740 & .739 & 6.240 & .740 & 839.188 & .000 & 1.143 \\
\hline $\begin{array}{l}\text { Model 1: Predictors: (Constant), V37 } \\
\text { Dependent Variable: \% rented 01 }\end{array}$
\end{tabular}

The next stage of the research involved splitting the data according to the level of median rent paid in a suburb. A weekly rent of $\$ 230$ was selected as the cut-off point between the lower rent model and the higher rent model. Median rent was 
thought to act as a useful proxy for house prices and is strongly correlated to incomes. The matrix representing the higher rent models is shown in Appendix 2 and the models in Table 5 . This model is very clearly dominated by the percentage of married variable, with the income being less important. However, the income variable showed up as being more significant in the lower rent models. It is interesting to note how the correlation coefficient for income is only -.170 in the high rent matrix in Appendix 2, but increases to -.644 in the low rent matrix in Appendix 3. This result supports the contention that slippage in ownership rates over time is most likely to be apparent in the low-income group. The lower rent models are shown in Tables 6 and 7. Table 6 includes the standard predictor variables and Table 7 the transformed hybrid variable (percentage married multiplied by log of income). The lower rent model is likely to represent renters who have the most difficulty bridging the deposit gap. Traditionally, significant numbers in this group could only switch to ownership with some form of government assistance. However, government assistance was progressively withdrawn after the mid-1980's.

Table 5: Model summaries: high rent models

\begin{tabular}{|c|c|c|c|c|c|c|c|c|}
\hline & $\mathrm{R}$ & $\begin{array}{c}\mathrm{R} \\
\text { Square }\end{array}$ & $\begin{array}{l}\text { Adjusted } \\
\text { R Square }\end{array}$ & \begin{tabular}{|l} 
Std. Error of \\
the Estimate
\end{tabular} & $\begin{array}{l}\text { Change } \\
\text { Statistics }\end{array}$ & & & \\
\hline Model & & & & & $\begin{array}{l}\text { R Square } \\
\text { Change }\end{array}$ & F Change & df1 & $\mathrm{df} 2$ \\
\hline 1 & .927 & .859 & .858 & 4.598 & .859 & 805.088 & 1 & 132 \\
\hline 2 & .945 & .893 & .892 & 4.018 & .034 & 41.888 & 1 & 131 \\
\hline 3 & .949 & .900 & .898 & 3.894 & .007 & 9.449 & 1 & 130 \\
\hline 4 & .951 & .904 & 901 & 3.832 & .004 & 5.254 & 1 & 129 \\
\hline 5 & .953 & .908 & .904 & 3.773 & .004 & 5.032 & 1 & 128 \\
\hline 6 & .954 & .911 & .907 & 3.727 & .003 & 4.188 & 1 & 127 \\
\hline \multicolumn{9}{|c|}{$\begin{array}{l}\text { Model 1: Predictors: (Constant), \% married01 } \\
\text { Model 2: Predictors: (Constant), \% married01, Waitakere } \\
\text { Model 3: Predictors: (Constant), \% married01, Waitakere, \%maori01 } \\
\text { Model 4: Predictors: (Constant), \% married01, Waitakere, \%maori01, Log Inc } \\
\text { Model 5: Predictors: (Constant), \% married01, Waitakere, \%maori01, Log Inc, Auckland } \\
\text { Model 6: Predictors: (Constant), \% married01, Waitakere, \%maori01, Log Inc, Auckland, } \\
\text { North shore } \\
\text { Dependent Variable: \% rented } 01\end{array}$} \\
\hline
\end{tabular}

Building models to explain the percentage of rental properties in an area is complicated by a number of factors. Some suburbs have a strong institutional influence such as military housing and government-owned rental housing occupied by low-income families. In the case of Naval housing in Auckland, this is often located on prime sites near the harbour. Suburbs with a high percentage of retired people may show a high percentage of ownership with relatively modest incomes. This can arise when older people are asset rich and have no debts. Other 
suburbs are changing rapidly due to the impact of property development. For example, the boom in owner-occupied inner city apartment building has tended to displace and submerge the traditional population of inner city renters. The biggest swing to rental properties has occurred in established suburbs comprising mainly single-family detached homes. The biggest percentage swing away from rentals occurs in greenfields areas on the city fringes where the new housing is predominantly owner-occupied. Further research will be needed to quantify these variables.

Table 6: Model summary: low rent models

\begin{tabular}{|c|c|c|c|c|c|c|c|c|c|c|}
\hline & $\mathrm{R}$ & $\begin{array}{c}\mathrm{R} \\
\text { Square }\end{array}$ & $\begin{array}{c}\text { Adjusted } \\
\text { R Square }\end{array}$ & $\begin{array}{c}\text { Std. Error } \\
\text { of the } \\
\text { Estimate }\end{array}$ & $\begin{array}{c}\text { Change } \\
\text { Statistics }\end{array}$ & & & & & $\begin{array}{c}\text { Durbin- } \\
\text { Watson }\end{array}$ \\
\hline Model & & & & $\begin{array}{c}\text { R Square } \\
\text { Change }\end{array}$ & F Change & df1 & df2 & $\begin{array}{c}\text { Sig. F } \\
\text { Change }\end{array}$ & \\
\hline 1 & .711 & .505 & .502 & 9.138 & .505 & 167.504 & 1 & 164 & .000 & \\
\hline 2 & .823 & .678 & .674 & 7.394 & .173 & 87.519 & 1 & 163 & .000 & \\
\hline 3 & .842 & .709 & .703 & 7.057 & .030 & 16.925 & 1 & 162 & .000 & \\
\hline 4 & .850 & .722 & .715 & 6.914 & .013 & 7.778 & 1 & 161 & .006 & \\
\hline 5 & .857 & .734 & .726 & 6.782 & .012 & 7.324 & 1 & 160 & .008 & 1.544 \\
\hline $\begin{array}{l}\text { Model 1: Predictors: (Constant), \% married 01 } \\
\text { Model 2: Predictors: (Constant), \% married 01, Rents 01 } 01\end{array}$ \\
Model 3: Predictors: (Constant), \% married 01, Rents 01, Auckland \\
Model 4: Predictors: (Constant), \% married 01, Rents 01, Auckland, Log Inc \\
Model 5: Predictors: (Constant), \% married 01, Rents 01, Auckland, Log Inc, North shore \\
Dependent Variable: \% rented01
\end{tabular}

Table 7: Model summary: low rent hybrid model

\begin{tabular}{|c|c|c|c|c|}
\hline Model & $\mathrm{R}$ & $\mathrm{R}$ Square & $\begin{array}{c}\text { Adjusted R } \\
\text { Square }\end{array}$ & $\begin{array}{c}\text { Std. Error of the } \\
\text { Estimate }\end{array}$ \\
\hline 1 & .795 & .632 & .629 & 7.03 \\
\hline Model 1: Predictors: (Constant), V37 \\
\hline
\end{tabular}

\section{CONCLUSION}

The snap shot of private sector renters provided by the survey reveals that difficulties with housing affordability are the main reasons why more people aren't switching to ownership. The decline in home ownership rates in New Zealand since 1986 is mostly a reflection of the decline in home affordability, since wages and salaries have not kept up with increases in house prices, particularly in the Auckland region. The survey also showed most renters still aspire to ownership, but are having difficulty getting a deposit together. 
The findings from the survey are confirmed by the quantitative analysis undertaken in the second part of this paper using census data. Household income clearly has the most influence on tenure decisions in the lower rent areas because renters in these areas have the most difficulty saving for a deposit. This analysis also showed that the percentage of married people in a suburb is strongly correlated to homeownership. Marriage appears to represent a settling down period for couples, where there is a strong nesting instinct and a wish to bring children up in a stable environment. These values are in line with the traditional values associated with home ownership.

There are no easy answers to reversing the decline in the rate of home ownership in New Zealand. Increased wages and salaries can only be sustained by real increases in productivity. On the international scene, New Zealand's wages and salaries are seen as relatively high in comparison with our competitors, so there may be little room to move here. Families can increase their ability to raise a deposit and service a mortgage when both partners have jobs, but the trade-off is generally less family time. The time when the extra salary is needed is often just when the children need a large amount of parental involvement.

Will the increase in house prices continue? Most probably they will. The income taxation system currently favours investment in housing and there are strong political pressures for the retention of the status quo in this area. Also, demand pressures, particularly in Auckland, will be likely to keep increases in house prices ahead of the general rate of inflation. In addition, building costs have a history of increasing at about the rate of inflation and the current controversy about poor quality "leaky homes" is likely to result in stricter building regulations and more costly new houses.

In the past, a variety of government incentives have been used to make it possible for lower income families to purchase their own houses. These included subsidised low interest loans, sweat equity programmes, mortgage repayment guarantees, suspensory loans, capitalisation of the family benefit and the use of the accommodation supplement for making mortgage payments. It seems clear that the government does have a vital role to play in the mortgage area that could go well beyond traditional direct subsidies as previously described.

\section{REFERENCES}

AMP Banking. (2002), Home Affordability Report June, Vol 12, No.2.

Auckland Regional Council. (1999), Affordable Housing in the Auckland Region. Regional Growth Forum Report. 
Bourassa, S. (1995), A Model of Tenure Choice in Australia. Journal of Urban Economics, Vol. 32, pp 1163-1173.

Bourassa, S. (2000), Ethnicity, Endogeneity and Housing Tenure Choice. Journal of Real Estate Finance and Economics, Vol. 20, No. 3.

Chapman, R. (1981), To Rent or Buy? Research Paper 82/1, National Housing Commission, Wellington.

Christiansen, W. (1991), Mahoney's Urban Land Economics. NZ Institute of Valuers, Wellington.

Crews, G. and Hopkins, J. (1999), New Zealand Mortgage Affordability Index. Massey University Real Estate Analysis Unit.

Goodman, A. (1988), An Econometric Model of Housing Price, Permanent Income, Tenure Choice and Housing Demand. Journal of Urban Economics, Vol. 23, pp 327-252.

Goodman, A. (2002), Estimating Equilibrium Housing Demand for 'Stayers'. Journal of Urban Economics, Vol 51, No. 1.

Fisher, L. (2002), Tenure Choice and Labour Market Outcomes. Housing Studies, Vol 17, No. 1.

Green, R. and Hendershott, P. (1999), Home Ownership and Unemployment in the U.S. National Multi-Unit Housing Council, Washington. www.nmhc.org/publicat/recent/unemploy/body.html

Haffner, M. and Dol, C. (2000), Housing Statistics in the European Union 2000. Delft University of Technology, The Netherlands.

Hargreaves, R. (2002), To Rent or Buy: That is the Question. NZ Property Journal, March.

Kan, K. (2000), Modelling Housing Tenure Choice. Journal of Urban Economics, Vol 48, No. 1.

Knight, J. and Eakin, C. (1997), A New Look at the Home Ownership Decision. Real Estate Issues, Vol 23, No.2, pp 20-29.

Ministry of House. (2002), Annual Report for Year End 30 th June 2001. www.minhousing.govt.nz/annreport.html 
Norusis, M. (1996), SPSS 6.1 Guide to Data Analysis. Prentice Hall.

O'Dea, D. (2000), The Change in New Zealand's Income Distribution. Treasury Working Paper 00/13. http://www.treasury.govt.nz/workingpapers/2000/twp00-13.pdf

Pahl, R. (1998), Some Remarks on Informal Work, Social Polarisation and Social Structure. International Journal of Urban and Regional Research, Vol 12, No. 2, pp 247-267.

Quotable Value. (2002), NZ Real Estate Market- Half Year Ended June 2002. Quotable Value.

Statistics New Zealand. (1998), Housing. Statistics New Zealand.

Statistics New Zealand. (2001), Household Expenditure Survey. Statistics New Zealand.

Statistics New Zealand. (2002), Meshblock Database-CD- ROM. Statistics New Zealand, http://www.statisticsnz.govt.nz. 
APPENDIX 1

Correlations-Auckland region

\begin{tabular}{|c|c|c|c|c|c|c|c|c|c|}
\hline & $\begin{array}{c}\text { \%rented } \\
01\end{array}$ & $\begin{array}{c}\text { North } \\
\text { shore }\end{array}$ & Waitakere & Auckland & $\begin{array}{r}\text { \%20-34 } \\
\text { in 01 }\end{array}$ & $\begin{array}{c}\text { \%Maori } \\
01\end{array}$ & $\begin{array}{c}\text { Log } \\
\text { Inc }\end{array}$ & $\begin{array}{c}\text { Rents01 } \\
\text { \%married } \\
01\end{array}$ \\
\hline \%rented01 & 1.000 & -.166 & -.260 & .453 & .524 & .300 & -.460 & -.285 & -.854 \\
\hline North shore & -.166 & 1.000 & -.202 & -.316 & -.143 & -.223 & .114 & .171 & .233 \\
\hline Waitakere & -.260 & -.202 & 1.000 & -.316 & -.061 & .136 & -.105 & -.129 & .092 \\
\hline Auckland & .453 & -.316 & -.316 & 1.000 & .447 & -.323 & .127 & .276 & -.445 \\
\hline \%20-34in 01 & .524 & -.143 & -.061 & .447 & 1.000 & .027 & -.032 & .143 & -.689 \\
\hline \%Maori01 & .300 & -.223 & .136 & -.323 & .027 & 1.000 & -.498 & -.616 & -.374 \\
\hline Log Inc & -.460 & .114 & -.105 & .127 & -.032 & -.498 & 1.000 & .733 & .379 \\
\hline Rents01 & -.285 & .171 & -.129 & .276 & .143 & -.616 & .733 & 1.000 & .176 \\
\hline \%married01 & -.854 & .233 & .092 & -.445 & -.689 & -.374 & .379 & .176 & 1.000 \\
\hline
\end{tabular}

\section{APPENDIX 2}

\section{Correlations- high rent}

\begin{tabular}{|c|c|c|c|c|c|c|c|c|c|}
\hline & $\begin{array}{c}\text { \%rented } \\
01\end{array}$ & $\begin{array}{c}\text { North } \\
\text { shore }\end{array}$ & Waitakere & Auckland & $\begin{array}{c}\text { \%Maori } \\
01\end{array}$ & $\begin{array}{c}\text { Rents } \\
01\end{array}$ & $\begin{array}{c}\% 20-34 \\
\text { in 01 }\end{array}$ & $\begin{array}{c}\text { Log } \\
\text { Inc }\end{array}$ & $\begin{array}{c}\% \text { married } \\
01\end{array}$ \\
\hline \%rented01 & 1.000 & -.158 & -.342 & .665 & .207 & .178 & .723 & -.170 & -.927 \\
\hline North shore & -.158 & 1.000 & -.181 & -.529 & -.052 & -.184 & -.235 & -.168 & .227 \\
\hline Waitakere & -.342 & -.181 & 1.000 & -.261 & .344 & -.202 & -.085 & -.045 & .173 \\
\hline Auckland & .665 & -.529 & -.261 & 1.000 & -.037 & .319 & .507 & .180 & -.635 \\
\hline \%Maori01 & .207 & -.052 & .344 & -.037 & 1.000 & -.377 & .406 & -.203 & -.382 \\
\hline Rents 01 & .178 & -.184 & -.202 & .319 & -.377 & 1.000 & .154 & .557 & -.142 \\
\hline $\begin{array}{c}\text { \%20-34 in } \\
01\end{array}$ & .723 & -.235 & -.085 & .507 & .406 & .154 & 1.000 & -.050 & -.812 \\
\hline Log Inc & -.170 & -.168 & -.045 & .180 & -.203 & .557 & -.050 & 1.000 & .144 \\
\hline $\begin{array}{c}\text { \%married } \\
01\end{array}$ & -.927 & .227 & .173 & -.635 & -.382 & -.142 & -.812 & .144 & 1.000 \\
\hline
\end{tabular}


APPENDIX 3

Correlations-low rent

\begin{tabular}{|c|c|c|c|c|c|c|c|c|c|}
\hline & $\begin{array}{c}\text { \%rented } \\
01\end{array}$ & $\begin{array}{c}\text { North } \\
\text { shore }\end{array}$ & Waitakere & Auckland & Rents 01 & $\begin{array}{c}\text { \%20-34 } \\
\text { in 01 }\end{array}$ & $\begin{array}{c}\text { \%Maori } \\
01\end{array}$ & $\begin{array}{c}\text { \%married } \\
01\end{array}$ & $\begin{array}{c}\text { Log } \\
\text { Inc }\end{array}$ \\
\hline \%rented 01 & 1.000 & -.067 & -.330 & .346 & -.588 & .331 & .196 & -.711 & -.644 \\
\hline North shore & -.067 & 1.000 & -.168 & -.174 & .192 & .000 & -.147 & .109 & .096 \\
\hline Waitakere & -.330 & -.168 & 1.000 & -.317 & .267 & -.025 & -.066 & .159 & .107 \\
\hline Auckland & .346 & -.174 & -.317 & 1.000 & .041 & .366 & -.369 & -.337 & -.190 \\
\hline Rents 01 & -.588 & .192 & .267 & .041 & 1.000 & .083 & -.228 & .263 & .451 \\
\hline \%20-34 in 01 & .331 & .000 & -.025 & .366 & .083 & 1.000 & -.023 & -.493 & -.222 \\
\hline \%Maori 01 & .196 & -.147 & -.066 & -.369 & -.228 & -.023 & 1.000 & -.423 & -.176 \\
\hline \%married 01 & -.711 & .109 & .159 & -.337 & .263 & -.493 & -.423 & 1.000 & .599 \\
\hline Log Inc & -.644 & .096 & .107 & -.190 & .451 & -.222 & -.176 & .599 & 1.000 \\
\hline
\end{tabular}

